\title{
Physico-Chemical and Bacteriological Analysis of Eripa and Erin- Ijesa Waterfalls used for Drinking \& Recreational Purposes in Osun State, Nigeria.
}

\author{
${ }^{1}$ G. O. Oyeleke, ${ }^{1}$ E.B. Akinro, ${ }^{2}$ T. Busari, ${ }^{2 *}$ T.P. Olakunle \\ ${ }^{I}$ Department of Science Laboratory Technology, Osun State Polytechnic, Iree, Nigeria \\ ${ }^{2 *}$ Department of Applied Sciences, Osun State Polytechnic, Iree, Nigeria
}

\begin{abstract}
Physico-chemical and bacteriological analysis of the two water falls were carried out. The results obtained were compared with EPA and WHO standards for drinking and recreational water. The water sources were within the standard set for $\mathrm{pH}$, Total dissolved solids, Total solid, acidity, chloride and iron contents. For bacteriological analysis, the two samples did not comply with bacteriological standards because the total coliforms could higher than 1,300 MPN/ml, Vibrio cholerae counts and Salmonella - Shigella counts were also high. The pathogens in water for drinking and recreational purposes may pose a threat in public health and even other microorganisms that may also be present. The pathogens and other microbes are all concerned in gastro-intestinal water source diseases that usually affect man and aquatic lives at large.
\end{abstract}

Key words: Drinking water, Recreational, Waterfall, Pathogens.

\section{Introduction}

Water is the most essential needs of the continued existence of all human lives and the equilibrium of natural life. Water sources are at every stage of human lives and they become one of the most important necessities of people [1]. It is effectively and efficiently put into use by plants, animals, microorganisms and man. In the microbial world, no single microorganisms has been discovered to be active at the extreme lack of water for the single reason that man cannot exist without water [1]. Increase in human population exert an enormous pressure on the provision of safe drinking water especially in developing countries [2]. Many infectious diseases are transmitted by water through the fecal-oral route. Diseases contacted through drinking water kill about 5million children annually and make $1 / 6^{\text {th }}$ of the world population risk [3]. Water related diseases continue to be one of the major health problems globally. The high prevalence of diarrheal among children and infants can be traced to the use of unsafe water and unhygienic practices [4]. Therefore, maintaining a safe drinking water remain essential to human health as transient bacterial contamination may have implication well beyond a period of acute-self limited illness [ 4 ]. Water of good drinking quality is of basic important to human physiology, although, guideline for bacteriological water differs from country to country, but they all conform to WHO recommendation [5]. The standard for drinking water are more stringent than those for recreational, constraints are the major obstacles in the provision of water of good quality in developing countries and rural areas [5]. In Nigeria, majority of the rural populace do not have access to portable water and therefore, depend on well, stream and river water for domestic use [6]. The bacterial qualities of groundwater, pipe borne water and other natural water supplies in Nigeria have been reported to be unsatisfactory, with coliforms counts for exceeding the level recommendation by WHO [6]. The research is aimed at investigating the physico-chemical parameters and bacterial counts of certain genera in both Eripa and Erin-Ijesa waterfalls respectively.

\section{Materials And Methods}

Water samples from the two waterfalls (Eripa and Erin-Ijesa) were randomly collected for physicochemical bacteriological analyses in sterile bottles and taken to the laboratory aseptically.

\subsection{Physico-Chemical Analysis}

The physico-chemical analysis conducted are: determination of $\mathrm{pH}$, colour, Odour, turbidity, total solids, total dissolved solids, conductivity, acidity, iron and chloride contents using the methods of FAO [7].

\subsection{Bacteriological Analysis}

Bacteriological characteristics were determined according to Bezeidenhout [8], the Most Portable Number-Multiple tube technique was used for coliform concentration. Salmonella-Shigella agar and Thiosulphate citrate bile salt sucrose agar were used to determine Salmonella - Shigella and Vibrio cholerae respectively. Every plate was incubated at $37^{\circ} \mathrm{C}$ for 24 hours. Gram staining and biochemical reactions were used 
to confirm the presumptive colonies where each plate was given a positive or negative score. The isolates were determined through conventional biochemical test, Standing Committee of Analysis [9].

\section{Results And Discussion}

The physico-chemical analysis conducted involved the colour, Odour, total solids, total dissolved solids, turbidity, acidity, chloride and ion contents which are all presented in Table 1.

The two waterfalls are colourless and also no objectionable odour (Table 1). The $\mathrm{pH}$ of the water sources ranged from 6.5 and 6.9 respectively, while the turbidity of the water samples ranged between 3.5 and 3.8 NTU (Both waterfalls). The conductivity measured at $(\mu \mathrm{s} / \mathrm{cm})$ ranged between 465 and $580(\mu \mathrm{s} / \mathrm{cm})$. Eripa Waterfalls has the lower conductivity of $465 \mu \mathrm{s} / \mathrm{cm}$ while Erin-Ijesa waterfall has the higher conductivity of $580(\mu \mathrm{s} / \mathrm{cm})($ Table 1$)$.

Table 1:Physico-Chemical Analysis of the two Waterfalls

\begin{tabular}{|c|c|c|}
\hline Parameters & Eripa Waterfall & Erin-Ijesa Waterfall \\
\hline Colour & Colourless & Colourless \\
\hline Odour & $\mathrm{U}$ & $\mathrm{U}$ \\
\hline $\mathrm{pH}$ & 6.5 & 6.9 \\
\hline Conductivity $(\mu \mathrm{s} / \mathrm{cm})$ & 465 & 580 \\
\hline Turbidity (NTU) & 3.5 & 3.8 \\
\hline Total Solids (mg/L) & 410 & 390 \\
\hline Total Dissolved Solids (mg/L) & 336 & 320 \\
\hline Acidity & 0.1 & 0.1 \\
\hline Chloride content & 210 & 180 \\
\hline Iron Content & 0.1 & 0.2 \\
\hline & WHO STANDARD & EPA STANDARD \\
\hline Colour & Colourless & Colourless \\
\hline Odour & $\mathrm{U}$ & $\mathrm{U}$ \\
\hline $\mathrm{pH}$ & 6.5 & $6.5-8.5$ \\
\hline Conductivity $(\mu \mathrm{s} / \mathrm{cm})$ & NS & NS \\
\hline Turbidity (NTU) & 6.0 & 0.5 \\
\hline Total Solids (mg/L) & 500 & 500 \\
\hline Total Dissolved Solids (mg/L) & NS & NS \\
\hline Acidity & 0.3 & 0.3 \\
\hline Chloride content & 200 & 250 \\
\hline Iron Content & 0.3 & 0.3 \\
\hline
\end{tabular}

$\mathrm{U} \rightarrow$ Unobjectionable

NS $\rightarrow$ No Standard

Table 2: Bacteriological Analysis of Water

\begin{tabular}{|l|l|l|l|}
\hline Sample & Total coliform count & Salmonella-Shigella count & Vibrio cholerae count \\
\hline A (Eripa waterfall) & 1,300 & $3.6 \times 10^{4}$ & $5.6 \times 10^{4}$ \\
\hline B (Erin-Ijesa waterfall) & $>1,600$ & $5.0 \times 10^{4}$ & $4.0 \times 10^{4}$ \\
\hline WHO Standard & Zero/100ml & Zero & Zero \\
\hline EPA Standard & Zero & Zero & Zero \\
\hline
\end{tabular}

Table 3: Microbial isolates from the two waterfalls.

\begin{tabular}{|l|l|l|}
\hline Isolates & Eripa waterfall & Erin-Ijesa waterfall \\
\hline Escherichia coli & + & + \\
\hline Staphylococcus aureus & + & + \\
\hline Shigella sp. & + & + \\
\hline Vibrio cholera & + & + \\
\hline Pseudomonas sp. & + & + \\
\hline Klebsiella sp. & + & - \\
\hline Salmonella typhosa & + & + \\
\hline Proteus sp. & + & + \\
\hline
\end{tabular}

Total dissolved solids ranged between 320 and 336mgl while the total solids ranged between 390 and $410 \mathrm{mg} / \mathrm{L}$ (Table 1$)$. The acidity of the two waterfalls samples were the same $(0.1$ and 0.1 respectively) (Table 1). 
The chloride content ranged from 180 to 210 , while the Iron content ranged from 0.1 to 0.2 (Table 1).

The result of the bacteriological analysis of the two waterfall samples are shown in Table 2 . The total viable counts for the two sample sources were very high, which ranged between $4.0 \times 10^{4} \mathrm{cfu} / \mathrm{ml}$ to $5.0 \mathrm{x}$ $10^{4} \mathrm{cfu} / \mathrm{ml}$. Eripa waterfall sample has higher microbial load of $5.0 \times 10^{4}$ while Erin-Ijesa waterfall sample has lower microbial load of $4.0 \times 10^{4}$ (Table 2).

The most Probable Number (MPN) for positive total coliform count of the samples from the two sources (Eripa and Erin-Ijesa waterfalls) ranged from 1,300 to >1,600MPN per 100ml. Sample B (Erin-Ijesa waterfall sample) has the higher total coliform count greater then $1,600 \mathrm{MPN} / 100 \mathrm{ml}$, while the other sample (Eripa waterfall sample) has the lower total coliform counts of 1,300MPN/100ml. (Table 2).

The Vibrio cholerae count and the Salmonella and Shigella counts for samples A and B (Eripa and Erin-Ijesa waterfalls) ranged differently. The Vibrio cholera count of the two samples ranged between $4.0 \mathrm{x}$ $10^{4} \mathrm{cfu} / \mathrm{ml}$ to $5.6 \times 10^{4} \mathrm{cfu} / \mathrm{ml}$ in which the Eripa waterfall sample has the higher count (Table 2).

The Salmonella and Shigella counts for the two samples also ranged differently. The counts ranged between $3.6 \times 10^{4} \mathrm{cfu} / \mathrm{ml}$ to $5.0 \times 10^{4} \mathrm{cfu} / \mathrm{ml}$, while the Erin-Ijesa waterfall sample has the higher count (Table 2). At the end of this investigation, both Eripa and Erin-Ijesa waterfalls have the following bacteria as being isolated from the samples analysed, they are Escherichia coli, Staphylococcus aureus, Shigella sp., Vibrio cholerae, Pseudomonas sp., Klebsiella sp. and Salmonella typhosa (Table 3). Klebsiella sp. was only isolated from Eripa waterfall sample and not isolated from Erin-Ijesa waterfall sample.

\section{Discussion}

The total coliform count for the two samples were very high in comparable to EPA standard for coliform bacteria in drinking water which is at zero total coliform per $100 \mathrm{ml}$ of water [10].

The presence of coliform in the samples may be as a result of pollution (faecal) [10,11]. None of the two samples is in order with EPA standard for coli-form in water.

The bacteria isolated from the two waterfall samples, which include Pseudomonas spp., Staphylococcus aureus, are of public health significance because they produce toxins, especially, Staphylococcus aureus that produce enterotoxin [10,12]. Greater number of Vibrio cholera, Salmonella typhosa, Shigella spp. isolated from the two water sample sources did not agree with EPA water standard for swimming purpose and if care is not taken where they are present they are very dangerous to health of individuals swimming in such water. However, the presence of these organisms in the waterfall samples may give rise to gastrointestinal infections, typhoid fever, diarrhoea, salmellosis, shigellosis and a host of other gastrointestinal disorders [10].

The $\mathrm{pH}$ of the samples determined were in line with the $\mathrm{pH}$ assigned by EPA as the standard $\mathrm{pH}$ of water which ranged from 6.5-8.5 but a little bit higher than WHO standard which is 6.5. Although, one can still recommend the $\mathrm{pH}$ as standard with a little difference shown in this study [10)

The colour and the odour of the two water samples determined showed that samples met the standard to which wholesome water should be, because it was determined as colourless and odourless [10].

The total dissolved solids of the water samples are in agreement with the environmental protection agency standard of $500 \mathrm{mg} / \mathrm{L}$ and even with WHO standard which is also at the same standard $(500 \mathrm{mg} / \mathrm{l})$. The total solids and total dissolved solids of any portable water could be attributed with the natural sources, sewage urban runoff, and even chemical that have seen used in the water treatment process [10], this could be fair rather than being hazardous to health [10]. The turbidity of the samples determined showed that the Eripa water sample met the standard of WHO but higher than the EPA standard while Eripa water sample which is a little bit higher than Eripa sample also met the WHO standard but above the EPA standard. The high turbidity level may be attributed to those parasites and bacteria causing infectious inhabiting in the water environment which were brought there during surface runoff and this tends to increase the turbidity $[10,12]$. The high turbidity makes the water to become cloudy and this also affects aquatic lives.

The chloride content of the water samples determined showed that the Erin-Ijesa water sample agreed with the EPA standard while the Eripa water sample was above the standard of WHO but in agreement with the EPA standard $[10,14]$. The chloride content recommended by EPA is $250 \mathrm{mg} / \mathrm{l}$ while that of WHO is $200 \mathrm{mg} / 1$ likewise, the iron content of the water sample was investigated and the results showed that both water samples are in agreement with EPA and WHO standard $[10,12]$.

\section{Conclusion And Recommendation}

Human activities around those waterfalls, such as defaecation defection may contribute to the level of contaminants in the water fall. These materials may be transported during surface runoff. Also, people should be educated on proper way of defaecating, that is, defaecation and other negative activities should be checked.

Finally, the organisms confirmed being associated with the two waterfalls are of public health significance which could result into infections if not properly taken care of. 


\section{Refernces}

[1] Karadag, Avrupa Birlgisu politikalan cercevesinde Turkiye, deki, sukaymaklan Yonetermmm Degarlendim limesi. TMMOB su POlitikalam Kongresi 21-23 mart sayfaNo 210 -219 Ankara

[2] I.O. Okonka, T.A Ogunnusi and M.C Olasogba. Comparative studies and microbial risk assessment of different water samples used for processing frozen sea foods in Ijora-Olopa, Lagos state, Nigeria. Africa journal of biotechnology, 7 (16): $2902-2907$

[3] J.M. Highes and J.P Koplan saving lives through global safe water. Journal of engineering infectious disease 11(10); (2005), 163616377 .

[4] WHO, 2004. Water sanitation and Health programme managing water in the home. Accelerated health gains from improved water sources. World Health organization. www.who.int.

[5] A. Lamikanra. Essential microbiology for students and practioners of pharmacy, medicine and microbiology. $2^{\text {nd }}$ edition. Ankara Books (2).

[6] O.O Dada, C.A Okuofu and E. Obele. Fecal pollution of well water in Zaria city, Nigeria, savannah.

[7] Food and Agriculture organization (FAO). Chemical analysis manual for food and water, $5^{\text {th }}$ Ed. FAO ROME (1997), 1:20-26.

[8] C.C. Bezuidenhout, N. Mthenbu, T. Puckree and J. Lin. Microbiological evaluation of the mhlathize river kwazuln-nation (RSA). Water S.A (2002). 28:281-286.

[9] Standing Committee of Analysis. The microbiology of drinking water. Part 1- water quality and public health methods for the examination of water and associated materials. Environment agency (2002). http://w.w.w.environment.

[10] EPA. US. Environment protection agency, safe drinking water act amendment (2002). http://w.w.w.epa.gov/safe water /mcl.ml.

[11] M.I. Osuinde and N.R Eneuzie. Bacteriological analysis of ground water. Nigeria journal of microbiology (1999). Vol.13:47-54.

[12] F. Ballester and J. Sunyer. Drinking water and gastrointestinal disease, need of better understand and an improvement in public health surveillance. Journal of epidemol community health. (2000). 54:3-5

[13] J. Schwartz, R. Levin and R. Goldstein. Drinking water turbidity and gastrointestinal illness in the elderly of Philadelphia. J. epidermal community health. (2000). 54:45-51.

[14] WHO. Water sanitation and health programme managing water in the home accelerated health gain from improved water sources. World health organization (2004). www.who.int. 